\title{
T4 - Registro universitario y red social de investigadores de la Universidad de San Carlos de Guatemala
}

\author{
Julio Estrada*, Federico Nave, Gerardo Arroyo \\ Dirección General de Investigación (Digi), Universidad de San Carlos de Guatemala (Usac)
}

*Autor al que se dirige la correspondencia: juliostrada@digi.usac.edu.gt

\section{Resumen}

$\mathrm{E}$ 1 Registro Universitario de Investigadores (RUI) es un catálogo creado por la Digi a principios del 2015, enfocado a conocer el recurso humano que forma parte del Sistema de Investigación de la Usac. El registro busca cuantificar y calificar las características de los profesionales dedicados a la investigación, requiriendo información general, como datos personales, formación académica, profesión y docencia, y específicas como experiencia en investigación, especialidad y publicaciones. Se implementó un formulario en línea utilizando el software de código abierto LimeSurvey. El producto actual de este proceso, son 917 profesionales registrados, de los cuales el 58\% son hombres y el $42 \%$ mujeres; $45 \%$ son $<40$ años, $40 \%$ entre 40 y 55 años y $15 \%>56$ años. La investigación es multidisciplinaria, $49.3 \%$ de los investigadores se enfocan en el área social, $56.5 \%$ en el área tecnológica y $26.1 \%$ en el área de salud. El 53\% trabaja en docencia, de los cuales el 43\% son profesores titulares. Del desarrollo del registro, surgen varias ideas, como la capacitación, pero también la necesidad de relacionar a los investigadores entre sí. En consecuencia se implementa la Red Social de Investigadores Digi-Usac como un servicio para estimular esas relaciones, identificando intereses comunes, socializando perfiles académicos y laborales, compartiendo conocimientos y promoviendo la colaboración científica. El sistema de investigación se vitaliza conociendo su potencial, pero se reconforta viendo surgir nuevas generaciones de investigadores e investigadoras en sus diferentes áreas.

Palabras claves: Catálogo de investigadores, red social, colaboración científica, Web 2.0

\section{Abstract}

$\mathrm{T}$

The University register of researchers (RUI) is a catalogue created by Digi at the beginning of the year 2015, focused to meet the human resource that is part of the research system of Usac. The registry seeks to quantify and qualify professionals involved in research, features requiring are specific and general, such as personal data, education, profession and teaching information as well as their experience in research and publications. For this project, we implemented an online form, using LimeSurvey open source software. The product of this process, are 917 registered professionals, of whom $58 \%$ are men and $42 \%$ women; $45 \%$ are $<40$ years, $40 \%$ between 40 and 55 years and $15 \%>56$ years. The research is multidisciplinary, $49.3 \%$ of the researchers focus on the social area, $56.5 \%$ in the technological area and $26.1 \%$ in health area. $53 \%$ works in teaching, of which $43 \%$ are professors. By the development of the register, arise several ideas, such as training and the need for linking researchers. Consequently, the Social network of Digi-Usac researchers is implemented as a service to stimulate these relationships, identifying common interests, socializing academic and occupational profiles, sharing knowledge and promoting scientific collaboration. The research system is vitalized knowing their potential, but it is comforting to see emerge new generations of researchers in different areas.

Keywords: Catalogue of research, researchers, scientific collaboration, Web 2.0, social network. 